\title{
Persepsi Mahasiswa terhadap Karakteristik Dosen yang Efektif Pada Pengajaran Bahasa Indonesia di Kalbis Institute Jakarta Timur
}

\author{
Ajeng Tina Mulyana \\ (Program studi Pendidikan Guru Sekolah Dasar, Fakultas Ilmu Pendidikan Universitas MH. Thamrin)
}

\begin{abstract}
ABSTRAK
Artikel ini menyajikan studi penelitian yang dirancang untuk mengetahui karakteristik dosen yang efektif dalam mengajarkan bahasa Indonesia di fakultas ekonomi jurusan Akuntansi dan keunikan dosen Bahasa Indonesia dalam kemampuan bahasa, kemampuan komunikasi, perencanaan pembelajaran, keterampilan sosial dan emosional dan pengelolaan kelas, dalam pengajaran bahasa Indonesia sebagai Mata Kuliah Umum (MKU). Penelitian ini didasarkan pada lima kategori umum: kemampuan bahasa, kemampuan komunikasi, perencanaan pembelajaran, keterampilan sosial dan emosional, pengelolaan kelas. Sedangkan persepsi mahasiswa akan dibedakan untuk mahasiswa semester 1 dan semester 5. Sample semester 1 akan diambil dari jurusan akuntansi, sedangkan semester 5 diambil dari jurusan komunikasi. Kategori umum ini akan dilihat dari persepsi mahasiswa fakultas ekonomi jurusan akuntansi dan jurusan komunikasi di Kalbis Institute Jakarta Timur. Untuk mengukur variabel independen terhadap variabel dependen. Data penelitian dikumpulkan melalui kuesioner berdasarkan Lickert lima-titik. Kusioner dibagikan kepada 30 mahasiswa. Berdasarkan perhitungan data diperoleh hasil sebagai berikut, persepsi mahasiswa di Kalbis Institute pada pengajaran bahasa Indonesia didapatkan nilai rata-rata yang paling besar adalah kategori "keterampilan sosial dan emosional" yaitu sebesar 18,7. Sedangkan mean kumulatif diperoleh nilai 4.43 pada pertanyaan kelima yaitu "Dosen bahasa Indonesia mendorong lebih banyak berbicara di kelas" (kategori kemampuan komunikasi), median 278,56, dan standart deviasi 153,57. Diharapkan hasil penelitian ini dapat mengungkapkan keyakinan mahasiswa dalam pentingnya karakteristik yang efektif dalam pengajaran bahasa, khususnya Bahasa Indonesia sebagai Mata Kuliah Umum (MKU). Penelitian ini memberikan kontribusi untuk pemahaman tentang harapkan mahasiswa terhadap karakteristik yang efektif dosen bahasa Indonesia sebagai Mata Kuliah Umum (MKU); di samping itu, penelitian ini diharapkan akan memberikan kontribusi pada bidang pengajaran Bahasa Indonesia sebagai Mata Kuliah Umum (MKU) di Kalbis Institute Jakarta Timur. Selain itu, mampu meningkatkan kesadaran siswa tentang pentingnya mata kuliah bahasa Indonesia di perguruan tinggi.
\end{abstract}

Kata kunci: Persepsi mahasiswa, karakteristik dosen yang efektif, pengajaran Bahasa Indonesia, Kuantitatif desktiptif 


\section{PENDAHULUAN \\ Latar Belakang Masalah}

Pengajaran bahasa Indonesia sebagai Mata Kuliah Umum (MKU) sudah banyak diteliti di Indonesia, namun secara khusus yang membahas mengenai persepsi mahasiswa dengan karakteristik dosen yang efektif pada pengajaran Bahasa Indonesia sebagai Mata Kuliah Umum (MKU) masih sangat sedikit dijumpai, terlebih untuk dosen Kalbis Institute tentunya penelitian ini dapat membantu dosen dalam memperoleh IKD (Indeks Kumulatif Dosen) yang sangat memuaskan. IKD (Indeks Kumulatif Dosen) seperti layaknya IPK yang diberikan kepada mahasiswa, sebagai dasar penilaian atasan atas kinerja mengajar selama 1 (satu) semester. Artikel ini pun melihat dari dekat mengenai pengajaran Bahasa Indonesia dengan tinjauan karakteristik dosen yang efektif pada Mata Kuliah Umum (MKU) dari persepsi mahasiswa terhadap karakteristik dosen yang efektif. Artikel ini didasarkan pada asumsi bahwa dosen Bahasa Indonesia diharapkan menjadi unik pada proses pengajarannya karena bukan bagian dari mata kuliah pengembangan bidang. Keunikan ini diselidiki dalam lima kategori keterampilan utama yaitu: kemampuan bahasa, kemampuan komunikasi, keterampilan sosial dan emosional, perencanaan pembelajaran, dan pengelolaan kelas, sedangkan sample diambil dari mahasiswa semester 1 jurusan akuntansi dan mahasiswa semester 5 jurusan komunikasi. Penelitian ini berhubungan dengan Persepsi mahasiswa terhadap karakteristik dosen yang efektif dalam pengajaran Bahasa Indonesia.

\section{Kajian Teoretik}

Mengetahui persepsi mahasiswa terhadap karakteristik dosen yan efektif terhadap keberhasilan proses pembelajaran bahasa Indonesia sebagai Mata Kuliah Umum (MKU). Yang terdiri dari lima kategori umum yaitu kemampuan bahasa, kemampuan komunikasi, keterampilan sosial dan emosional, perencanaan pembelajaran, dan pengelolaan kelas. Mengevaluasi konsep dan mekanisme pengajaran bahasa Indonesia sebagai Mata Kuliah mum (MKU) yang selama ini diterapkan di kalbis Institute, berdasarkan persepsi mahasiswa tersebut akan memengaruhi terhadap keberhasilan proses pembelajaran bahasa Indonesia, sekalipun bahasa Indonesia hanya sebagai Mata Kuliah Umum (MKU). Penelitian ini membatasi masalah pada persepsi mahasiswa semester 1 jurusan akuntansi dan mahasiswa semester 5 jurusan komunikasi di terhadap persepsi pengajaran yang efektif pada pengajaran bahasa Indonesia sebagai Mata Kuliah Umum (MKU) di Kalbis Institute, yang ditinjau dari lima kategori umum yaitu: kemampuan bahasa, kemampuan komunikasi, perencanaan pembelajaran, keterampilan sosial dan emosional, pengelolaan kelas.

\section{Hakikat Persepsi}

Persepsi dapat dilihat dari definisi secara etimologis maupun definisi yang diberikan oleh beberapa orang ahli. Secara etimologis, persepsi berasal berasal dari kata perception (Inggris) berasal dari bahasa latin perception; dari percipare yang artinya menerima atau mengambil (Sobur, 2009:445). Menurut Leavit (dalam Sobur, 2009:445) persepsi dalam arti sempit adalah penglihatan, bagaimana cara seseorang melihat sesuatu, sedangkan dalam arti luas persepsi adalah pandangan atau pengertian yaitu bagaimana seseorang memandang atau mengartikan sesuatu. Persepsi didefinisikan sebagai suatu proses yang menggabungkan dan mengorganisir data-data indera kita (penginderaan) untuk dikembangkan sedemikian rupa sehingga kita dapat menyadari di sekeliling kita, termasuk sadar akan diri kita sendiri (Shaleh, 2009:110). Definisi persepsi adalah pengalaman tentang objek, peristiwa, atau hubungan-hubungan yang diperoleh dengan menyimpulkan informasi dan menafsirkan pesan. Persepsi ialah memberikan makna pada stimuli inderawi (sensory stimuli). Hubungan dengan persepsi sudah jelas. Sensasi adalah bagian dari persepsi. Walaupun begitu, menafsirkan makna informasi inderawi tidak hanya melibatkan sensasi, tetapi juga atensi, ekspektasi, motivasi, dan memori. Persepsi sebagai proses dimana individu mengatur dan mengintrepetasikan kesan-kesan sensoris mereka guna memberikan arti bagi lingkungan mereka.(Robins, 2008: 175). Namun, apa yang diterima seseorang pada dasarnya bisa berbeda dari realitas objektif. Walaupun seharusnya tidak perlu ada, perbedaan tersebut sering timbul. Lalu mengapa persepsi orang-orang berbeda untuk realitas yang sama? karena adanya perbedaan dalam perceptual selection, perceptual organization dan perceptual interpretation (Simamora, 2002: 105). Sedangkan 
menurut Walgito (2002: 271), persepsi merupakan proses psikologis dan hasil dari penginderaan serta proses terakhir dari kesadaran, sehingga membentuk proses berpikir.

Dari berbagai pengertian diatas dapat disimpulkan bahwa hakikat persepsi siswa adalah proses seseorang untuk mengetahui hal-hal yang ada disekitamya atau lingkungannya melafui panca inderanya yang dipengaruhi pengalamannya sehingga sadar akan apa yang telah diamati yang akhimya berpengaruh terhadap sikap dan perilakunya. Persepsi merupakan proses akhir dari pengamatan yang diawali oleh proses penginderaan, yaitu proses diterimanya stimulus oleh alat indera, kemudian individu ada perhatian, lalu diteruskan ke otak dan baru kemudian individu menyadari tentang sesuatu yang dinamakan persepsi. Dengan persepsi individu menyadari dapat mengerti tentang keadaan lingkungan yang ada disekitarnya.

\section{Karakteristik Dosen yang Efektif}

Peran dosen bukan hanya berperan sebagai penyampai informasi melainkan sebagai "director and facilitator' yaitu pengarah dan pemberi fasilitas untuk terjadinya proses belajar. Sedangkan Hamzah (2014:15-17) dalam bukunya "Profesi Kependidikan", menyatakan bahwa "Mengajar pada prinsipnya adalah membimbing siswa dalam kegiatan belajar-mengajar atau mengandung pengertian bahwa mengajar merupakan suatu usaha, mengorganisasi lingkungan dalam hubungannya dengan anak didik dan bahan pengajaran yang menimbulkan proses belajar". Pendapat tersebut sejalan dengan Rusdiana (2015: 147150) yang mendefinisikan mengajar adalah "Suatu aktivitas untuk mencoba menolong, membimbing seseorang untuk mendapatkan, mengubah, atau mengembangkan skill (kemampuan), ideals, appreciations (penghargaan) dan knowledge (pengetahuan).

Seorang guru harus memiliki kompetensi yaitu memiliki kemampuan dalam mengembangkan pengetahuan yang telah ia peroleh melalui pendidikan yaitu kemampuan dasar yang dapat mengimplikasikan apa yang seharusnya dilakukan seorang guru dalam melaksanakan tugasnya yang berarti bahwa kompetensi mengajar adalah kemampuan yang harus dimiliki seorang guru dalam menyampaikan materi pelajaran kepada anak didik yang semua itu merupakan suatu hal yang menggambarkan kuatifikasi ataupun kemampuan seorang guru, baik secara kuantitatif serta kualitatif yang diberikan guru yang bersangkutan. Pengembangan kompetensi keguruan bertolak dari pengembangan kompetensi dasar, yaitu kompetensi pedagogik, kompetensi kepribadian, kompetensi sosial, dan kompetensi profesional. Kemudain dari ke empat kompetensi itu penulis turunkan kedalam lima kategori umum karakteristik dosen yang efektif yaitu kemampuan bahasa, kemampuan komunikasi, perencanaan pembelajaran, keterampilan sosial dan emosional, pengelolaan kelas.

\section{Pengajaran Bahasa Indonesia di Universitas Sebagai Mata Kuliah Umum (MKU)}

Pemerintah Republik Indonesia melalui Undang-Undang sistem pendidikan Nasional (SISDIKNAS) menetapkan bahasa Indonesia sebagai pengantar dalam setiap tingkatan pendidikan nasional. Hal itu tercantum dalam UU RI Nomor 20 tahun 2003 tentang SISDIKNAS, BAB VII, Psl 33 ayat 1 yang

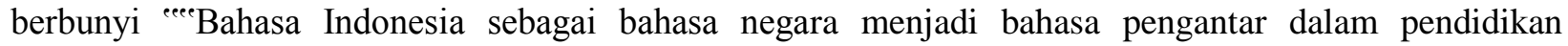
nasional ${ }^{\text {eee }}$. Sebagai implementasi dari UU SISDIKNAS tersebut, pemerintah menetapkan kurikulum Nasional dan Garis-Garis Besar Prorgram Pengajaran Bahasa Indonesia untuk setiap tingkatan sekolah yang ada di Indonesia.Untuk melihat sejauh mana realisasi kecintaan, kesetiaan, dan kebanggan bangsa Indonesia sebagai pemilik terhadap bahasa Indonesia, maka pihak-pihak yang terkait (teutama yang bergerak dalam bidang pendidikan) telah menetapkan bahasa Indonesia sebagai mata kuliah pengembangan kepribadian di perguruan tinggi pada seluruh Jurusan/Prodi/Fakultas dan wajib diambil/diprogramkan oleh seluruh mahasiswa sampai lulus.

Banyak mahasiswa baru yang mengikuti kuliah Bahasa Indonesia dengan setengah hati atau merasa sangat terpaksa, demi nilai atau indeks prestasi belaka. Sehingga tidak diherankan jika mahasiswa mengalami kejenuhan dalam belajar bahasa Indonesia. 


\section{Persepsi Mahasiswa terhadap Keterampilan Dosen yang Efektif}

Pengajaran bahasa menjadi lebih kompleks daripada mata pelajaran lain dan guru sehingga bahasa harus memperbarui pengetahuan metodologis dan memiliki lebih hubungan positif dengan siswa terlebih mahasiswa yang diajarkan adalah mahasiswa jurusan non-bahasa, lebih jauh lagi bahwa dosen bahasa harus memiliki kombinasi keterampilan mengajar yang baik dan kepribadian yang positif.

\section{Kemampuan Bahasa}

Kemampuan bahasa menjadi salah satu kategori umum karakteristik dosen yang efektif, mengajar bahasa Indonesia bisa dikatakan susah-susah gampang banyak mahasiswa yang menganggap bahwa bahasa Indonesia adalah bahasa pertama sehingga tidak perlu lagi dipelajari, terlebih jurusan yang dipilih pun adalah akuntansi yang secara langsung tidak berhubungan dengan mata kuliah bahasa Indonesia. Dikelas sering saya tanyakan kepada mahasiswa, "Anda secara jujur, lebih bangga pandai berbahasa Indonesia atau bahasa Inggris?" Mayoritas menjawab, "Bangga pandai berbahasa Inggris." Ada juga yang bangga pandai berbahasa Indonesia tetapi tidak banyak, dengan demikian maka seorang dosen bahasa Indonesia harus mampu dalam berbahasa Indonesia, bagaimana mengenai penyampainnya (dalam proses pengajaran) agar mahasiswa tertarik dengan mata kuliah bahasa Indonesia, bukan hanya semanta-mata karena tuntutan dari kampus sebagai Mata Kuliah Umum (MKU) yang harus ditempuh oleh setiap mahasiswa jurusan apapun.

\section{Kemampuan Komunikasi}

Kemampuan komunikasi, dalam proses pengajaran tidak sedikit dosen yang mampu berbahasa Indonesia dengan baik dan benar hanya saja hanya pada lingkup teoritis, namun secara paktik kemampuan komunikasi mereka masih sangat lemah. Kemampuan komunikasi sangat penting bagi seorang dosen karena salah satu prinsip pengajaran bahasa adalah komunikatif Brown (2008: 170), Prinsip ini menekankan bahwa kompetensi komunikatif merupakan tujuan dari kelas bahasa. Mengingat bahwa kompetensi komunikatif adalah tujuan dari kelas bahasa, pembelajaran perlu menunjuk ke arah semua komponennya: organisasi, pragmatis, strategis. dan psikomotor. Tujuan komunikatif akan tercapai dengan baik melalui penggunaan bahasa yang tidak hanya untuk tujuan akurasi tetapi juga untuk kefasihan atau kelancaran dan kegunaannya di dunia nyata. Sehingga seorang dosen harus mampu sebagai role model karena prinsip-prinsip linguistik berpusat pada bahasa itu sendiri dan bagaimana agar peserta didik memahami sistem linguistik yang kompleks. Berdasarkan teori-teori kebahasaan, dirumuskan prinsipprinsip mengenai pengajaran bahasa, antara lain kemampuan berbahasa adalah sebuah proses kreatif, maka siswa harus diberi kesempatan yang luas untuk mengkreasi ujaran-ujaran dalam situasi komunikatif yang sebenarnya, bukan sekedar menirukan dan menghafalkan, pemilihan materi pelajaran pada kebutuhan komunikasi dan penguasaan fungsi-fungsi bahasa, dan kaidah-kaidah dapat diberikan sepanjang hal itu diperlukan oleh siswa sebagai landasan untuk dapat mengkreasi ujaran-ujaran sesuai dengan kebutuhan komunikasi (Brown, 2008: 170).

\section{Perencanaan Pembelajaran}

Rencana pembelajaran merupakan arah bagi guru dalam melaksanakan pembelajaran di dalam kelas. Dalam rencana pembelajaran ini guru merencanakan kegiatan pembelajaran baik itu program tahun, program semester, program bulanan, program mingguan dan program harian. Rencana pembelajaran adalah catatan sistematis dari pikiran guru terhadap apa yang akan dilaksanakan selama pelajaran. Menurut Richards (2002: 50), rencana pembelajaran membantu guru berpikir lebih awal mengenai pelajaran, untuk menyelesaikan masalah dan kesulitan, memberikan susunan pelajaran, memberikan arah bagi guru dan memberikan catatan terhadap apa yang telah diajarkan. Banyak dosen yang menuliskan rencana pembelajaran harian, namun sebagian dosen tidak melakukannya, Pada prinsipnya semua guru yang akan masuk kelas memiliki perencanaan pembelajaran, hanya ada yang tertulis dan tidak tertulis (di kepala), masalahnya apabila rencana pembelajaran tersebut jauh dari rencana pembelajaran yang sudah diprogramkan oleh kampus itu sendiri. Banyak dosen yang beranggapan bahwa mahasiswa tidak peduli dengan perencanaan pembelajaran, hal itu keliru, di Kalbis Institute sudah tersedia aplikasi Kalbisphere, 
salah satu didalamnya memuat mengenai GBPP (Garis Besar Perencanaan Pembelajaran) yang terdiri dari Rencana Pembelajaran (RP) dan Rencana Tugas (RT), ada banyak mahasiswa yang sudah melihat GBPP tersebut sehingga perencanaan pembelajaran harus sudah direncanakan oleh dosen secara sistematis dan struktur sesuai dengan GBPP yang berlaku.

\section{Keterampilan sosial dan emosional}

Seorang dosen bahasa khususnya bahasa Indonesia, harus terampil dalam hal sosial dan emosional, karena mata kuliah bahasa Indonesia sebagai salah satu pilar terbentuknya suatu karakter. Di Kalbis Institute mata kuliah bahasa Indonesia masuk kedalam kabiro PMKPK (Pengelolaan Mata Kuliah Pengembangan Karakter), tentunya hal ini menjadi dasar pijakan bagai dosen dalam proses pengajaran. Dosen harus mampu memberikan teladan berbahasa baik secara lisan dan tulis bagi mahasiswa. Seorang dosen hendaknya mampu memberikan prinsip strategi investasi, Brown (2008: 166) dosen harus memiliki keterampilan sosial dan emosional, diantaranya:

1. Memberikan perhatian yang sama pada semua siswa.

2. Mengetahui gaya belajar masing masing siswa.

3. Menggunakan teknik pengajaran yang bervariasi disesuaikan dengan gaya belajar para siswa. Teknik yang bervariasi akan "menggapai" sebagian besar siswa.

Dosen harus memiliki keterampilan sosial dan emosional, belajar merupakan upaya sadar untuk mencapai perubahan perilaku secara keseluruhan yang meliputi aspek kognitif, afektif, dan psikomotorik. Keterampilan sosial dan emosional merupakan suatu aspek afektif yang memegang peranan penting dalam menentukan tingkat kesuksesan mengajar. Afeksi mengacu kepada sosial, emosi atau perasaan. Dosen harus mampu membangun rasa harga diri, rasa percaya diri, kenal akan diri sendiri, dan percaya akan kemampuan mahasiwanya (Brown, 2008:166-167). Jika seseorang guru terampil secara sosial dan emosional tentunya mampu melaksanakan tugas dengan baik dan biasanya selalu disukai oleh mahasiswanya.

\section{Pengelolaan kelas}

Pengelolaan kelas Guru bahasa Indonesia MKU (Mata Kuliah Umum) akrab sekali dengan maksud dari hasil pengajaran bahasa komunikatif, yakni, untuk para siswa menggunakan bahasa Indonesia yang baik dan benar dalam konteks lisan maupun tulisan untuk keperluan menyusun skripsi. Para dosen berusaha dengan keras di dalam kelas bagaimana agar mahasiswa jurusan non-kebahasan mampu tertarik dan berminat dalam proses pembelajaran. Pengelolaan pembelajaran dikelompokkan ke dalam tiga kategori: motivasi, hambatan, dan aturan-aturan (Richards, 2002: 49). Beberapa guru memperhatikan motivasi para siswa:

- Para siswa dalam kelas bahasa Indonesia adalah mahasiswa non-kebahasaan/jurusan diluar bahasa

-

Bahasa Indonesia hanya sebagai MKU (Mata Kuliah Umum) sehingga ada anggapan bukan mata kuliah pengembangan

- Aggapan Bahasa Indonesia adalah bahasa pertama yang sudah dipelajari sejak dari kecil

- Kelas gemuk/kelas dengan mahasiwa yang banyak, bagaimana mengelola suatu atmosfir pembelajaran yang ideal

Hal-hal inilah yang membuat pengelolaan kelas benar-benar sulit untuk guru namun siswa mengharapkan apapun kendalanya guru harus mampu mengelola kelas dengan baik dan menyenangkan. karakteristik dosen dan perilaku mengajar adalah faktor penting yang mempengaruhi motivasi dan belajar siswa. Temuan penelitian menunjukkan bahwa praktek mengajar dapat mempengaruhi prestasi belajar siswa. Juga, pembelajaran yang efektif tergantung pada sebagian besar pada perilaku guru di kelas.

\section{Tinjauan Literatur}

Karakteristik dosen dan perilaku mengajar adalah faktor penting yang mempengaruhi motivasi dan belajar siswa. Temuan penelitian menunjukkan bahwa praktek mengajar dapat mempengaruhi prestasi belajar siswa. Juga, pembelajaran yang efektif tergantung pada sebagian besar pada perilaku guru di kelas (Markley, 2004:5). Benson et al. (2001:9) percaya bahwa guru yang efektif adalah salah satu yang 
memiliki kemampuan untuk menyajikan informasi secara jelas, pemahaman dan cara memotivasi menjadi atribut lainnya, seperti pengetahuan yang kuat mengenai konten, keterampilan pedagogis, keterampilan interpersonal (Clark \& Walsh, 2002:15). Misalnya, Verner (2000) mewawancarai 17 guru untuk menyelidiki kualitas pengajaran yang efektif. Yang paling banyak diketemukan adalah karakteristik dosen yang menarik dalam proses mengajar, mendukung mahasiswa selama belajar, menunjukkan kemampuan interpersonal yang positif dengan mahasiswa, tersedia untuk mahasiswa, dan penggunaan humor dalam interaksi dengan siswa. (Richards, 2001:205) tercatat 12 karakteristik seperti, memberikan yang jelas dan instruksi terfokus, memantau kemajuan, menggunakan waktu kelas benar, dan memiliki kemampuan interpersonal yang positif dengan dengan mahasiswa dll.

\section{Fokus Masalah}

Penelitian ini memfokuskan masalah pada persepsi mahasiswa semester 1 jurusan akuntansi dan mahasiswa semester 5 jurusan komunikasi terhadap persepsi pengajaran yang efektif pada pengajaran bahasa Indonesia sebagai Mata Kuliah Umum (MKU) di Kalbis Institue, yang ditinjau dari lima kategori umum yaitu: kemampuan bahasa, kemampuan komunikasi, perencanaan pembelajaran, keterampilan sosial dan emosional, pengelolaan kelas.

\section{METODE PENELITIAN}

Jenis penelitian ini adalah penelitian kuantitatif dapat diartikan sebagai "metode penelitian yang berlandaskan pada filsafat positifisme, digunakan untuk meneliti pada populasi atau sampel tertentu" (Sugiyono, 2008: 8).Penelitian kuantitatif ini menggunakan pendekatan deskriptif. Alasan menggunakan metode tersebut digunakan karena ingin memasuki latar penelitian secara ilmiah dengan menggunakan alat bantu tes yang disebut kuisioner. Sampel adalah bagian atau wakil dari subyek yang diteliti (Arikunto, 2006: 131). Jumlah populasi diambil dari 2 kelas terdiri dari 60 orang mahasiswa, metode pengambilan sampel adalah random sampling. Teknik pengambilan random sampling dilakukan dengan cara undian. Mahasisiwa sebanyak 60 mahasiswa yang akan digunakan sebagai sampel terdiri dari 30 orang mahasiswa yang tersebar di dua kelas yakni kelas PAAK, PAIK. Mahasiswa ditiap-tiap kelas tersebut ditulis pada kertas kemudian dimasukkan ke dalam suatu tempat untuk kemudian dikocok. Setelah dikocok-kocok baru kemudian diambil atau dikeluarkan satu demi satu hingga mendapatkan 30 mahasiswa dari dua kelas tersebut. Instrumen adalah alat ukur yang digunakan untuk mengumpulkan data penelitian. Dalam penelitian ini instrumen yang digunakan berupa kuisioner. Kuisioner akan diukur menggunakan skala likert. Skala likert adalah penskalaan yang menggunakan distribusi respons setujutidak setuju sebagai dasar penentuan nilai (Creswell, 2016: 213). Angket yang digunakan dalam penelitian ini diperoleh dari kemudian dari hasil tersebut disesuaikan dengan pelaksanaan proses belajar mengajar yang efektif dari persepsi mahasiswa di fakultas ekonomi jurusan akuntansi Kalbis Institute.

\section{HASIL DAN PEMBAHASAN Subjek Penelitian}

Peserta dalam penelitian ini adalah mahasisiwa tahun ajaran 2016-2017, terdiri dari 15 mahasiswa dari jurusan akuntansi semester 1, dan 15 mahasiswa dari jurusan komunikasi semester 5, sehingga total keseluruhan sample 30 orang.

\section{Instrumen}

Pengumpulan data dilakukan melalui kuesioner berdasarkan lima skala likert dari "benar-benar setuju, sampai benar-benar tidak setuju", yang terdiri dari 20 pertanyaan didistribusikan ke dalam lima kategori utama yaitu: kemampuan bahasa, kemampuan komunikasi, perencanaan pembelajaran, keterampilan sosial dan emosional , pengelolaan kelas. Kemudian di isi oleh 15 mahasiswa semester 1 jurusan akuntansi dan 15 mahasiswa semester 5 jurusan komunikasi. Pertimbangn mengenai kategori karakteristik dosen yang efektif penulis adopsi dari tulisan Taqi (2014) mengenai "The Perspectives of Students in the College of Basic Education on the Characteristics of Effective English Language Teacher" pada awal kuesioner, para peserta diminta tentang usia mereka, semester, jurusan, bahasa pertama yang digunakan, 
kemudian didistribusikan ke dalam lima kategori utama yaitu: kemampuan bahasa, kemampuan komunikasi, perencanaan pembelajaran, keterampilan sosial dan emosional, pengelolaan kelas.

\section{Pengumpulan Data dan Analisis}

Kuesioner berisi 20 pernyataan yang akan dijawab dalam skala Likert mulai dari setuju untuk benar-benar tidak setuju. Kemudian pernyataan-pernyataan tersebut dianalisis secara rinci mengenai persepsi mahasiswa terhadap karaktersitik dosen yang efektif. Data tentang persepsi mahasiswa diperoleh melalui penyebaran quisioner yang telah diuji validitas dan realibilitas dengan menggunakan uji statistik manual dan SPSS.

Tabel.

Validitas

\begin{tabular}{|r|c|}
\hline TOTALPearson Correlation & 1 \\
Sig. (2-tailed) & \\
$\mathrm{N}$ & 30 \\
\hline
\end{tabular}

*.Correlation is significant at the 0.01 level (2-tailed).

*Correlation is significant at the 0.05 level (2-tailed).

Dari tabel 1.1. nilai 30 dilihat kedalam tabel validitas (Moment Person) dengan level significance 0.05 sehingga diperoleh angka tabel 0.361 kemudian dimasukan ke setiap pertanyaan. Sehingga diperoleh angka Pearson correlation P1 0.120, Pearson correlation P2 0.437, Pearson correlation P3 0.331, Pearson correlation P4 0.331, Pearson correlation P5 0.280, Pearson correlation P6 0.628, Pearson correlation P7 0.098, Pearson correlation P8 0.109, Pearson correlation P9 0.339, Pearson correlation P10 0.076, Pearson correlation P11 0.069, Pearson correlation P12 0.144, Pearson correlation P13 -0.260, Pearson correlation P14 -0.167, Pearson correlation P15 -0.266, Pearson correlation P16 0.291, Pearson correlation P17 0.110, Pearson correlation P18, -0.030 Pearson correlation P19 -0.433*, Pearson correlation P20 -0.298.

Tabel

Reliabilitas

Reliability Statistics

\begin{tabular}{|c|c|}
\hline $\begin{array}{c}\text { Cronbach's } \\
\text { Alpha }\end{array}$ & $\mathrm{N}$ of Items \\
\hline .44 & 20 \\
\hline
\end{tabular}

Dari tabel diperoleh reliabilitas dengan alpha cronbach ${ }^{\text {ee }}$ sebesar 0.449 .

\begin{tabular}{|c|c|c|c|c|c|c|c|c|}
\hline kelas & interval & frekuensi & $\begin{array}{l}\text { frekuensi } \\
\text { relatif } \\
\mathrm{Fi}(\%) \\
\end{array}$ & $\begin{array}{l}\text { nilai } \\
\text { tengah } \\
(\mathrm{Xi}) \\
\end{array}$ & Fi.Xi & $\mathrm{Xi}-\mathrm{X}^{-}$ & $\left(\mathrm{Xi}-\mathrm{X}^{-}\right)^{2}$ & $\begin{array}{l}\text { Fi. }\left(X i-X^{-}\right. \\
)^{2}\end{array}$ \\
\hline 1 & 73-76 & 1 & 3,33 & 74,5 & 248,33 & 204,06 & 41638,67 & 138795,6 \\
\hline 2 & $77-80$ & 6 & 20 & 78,5 & 1570 & 78,50 & 6162,25 & 123245 \\
\hline 3 & $81-84$ & 12 & 40 & 82,5 & 3300 & 82,50 & 6806,25 & 272250 \\
\hline 4 & $85-88$ & 6 & 20 & 86,5 & 1730 & 86,50 & 7482,25 & 149645 \\
\hline
\end{tabular}




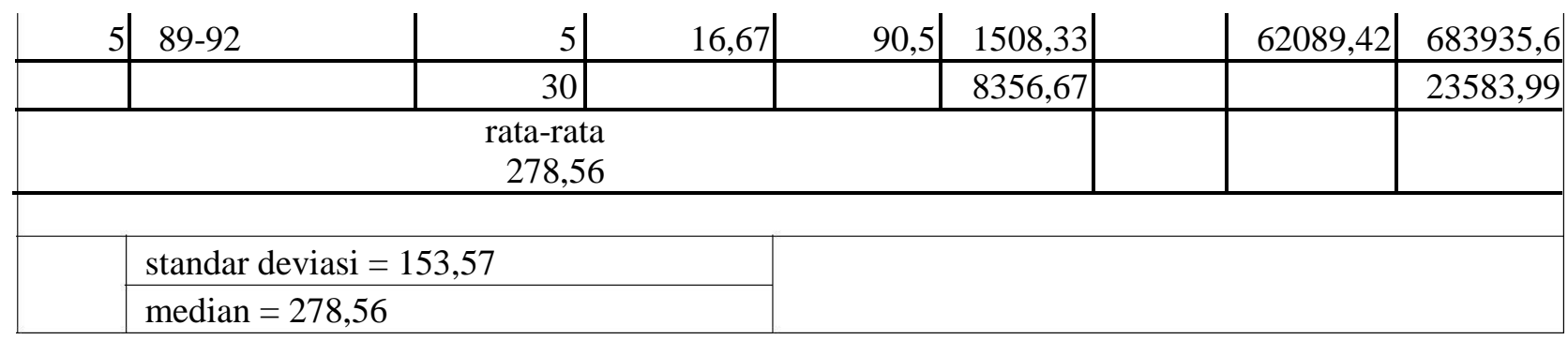

Tabel

Distribusi Frekuansi

Dari tabel 1.3 dapat dilihat distribusi frekuensi dari keseluruhan data dan diperoleh rata-rata 278.56, standar deviasi 153,57 dan median 278.56.

Tabel

Mean kategori

\begin{tabular}{|c|c|c|c|}
\hline No & Pertanyaan Kategori & Jumlah Total & Mean \\
\hline 1 & kemampuan bahasa & 501 & 16,7 \\
\hline 2 & kemampuan komunikasi & 536 & 17,8 \\
\hline 3 & perencanaan pembelajaran & 530 & 17,6 \\
\hline 4 & $\begin{array}{c}\text { keterampilan sosial dan } \\
\text { emosional }\end{array}$ & 562 & 18,7 \\
\hline 5 & pengelolaan kelas & 499 & 16,6 \\
\hline
\end{tabular}

Dari tabel 1.4 dapat dilihat frekuensi kumulatifnya sehingga didapatkan data persepsi mahasiswa terhadap karaktersitik dosen yang efektif dengan mean tertinggi 18,7 untuk kategori keterampilan sosial emosional, kemampuan komunikasi 17,8, perencanaan pembelajaran 17.6, kemampuan bahasa 16,7, pengelolaan kelas 16,6 .

\section{SIMPULAN}

Persepsi mahasiswa terhadap karakteristik dosen yang efektif berdampak pada pembelajaran mereka (Ghasemi \& Hashemi, 2011), persepsi mahasiswa ini bermanfaat untuk membantu dosen dalam memikirkan kembali teknik dan metode yang akan digunakan dalam proses pembelajaran pada penelitian ini diperoleh mean tertinggi yaitu pada kategori pertanyaan keterampilan sosial emosional. Persepsi ini menyimpulkan bahwa mahasiswa lebih menyukai dosen yang memiliki kedekatan sosial dan emosional.

DAFTAR REFERENSI

Arikunto, Suharsimi. (2006). Prosedur Penelitian Suatu Pendekatan

Praktik. Jakarta : Rineka Cipta.

Benson, L., Schroeder, P., Lantz, C., \& Bird, M. (2001). Student

perceptions of effective teachers. [Online], 27 Desember. 2016, http://www.usfca.edu/ess/sym2001/PDFbooks/pdf.

Brown, H. Douglas, Prinsip Pembelajaran dan Pengajaran

Bahasa. Amerika: Pearson Education, 2008.

Clark,J \& Walsh, J. (2002). Elements of a model of effective teachers. [online] 27 Desember. 2016, http://www.aare.edu.au02papwal02220.htm. 
Cresswell, W.Jhon.(2016). Research Design : Pendekatan Metode Kualitatif, Kuantitatif, dan Campuran. Yogyakarta: Pustaka Pelajar.

Markley, T. (2004). Defining the effective teacher: Current arguments in education. Essays in Education, 11(3),1-14.

Richards, J.C. (2001). Curriculum Development in Language Education. Cambridge: University Perss. Richards, Jack C dan Willy A. Renandya. (2002) Methodology In Language Teaching. USA: Cambridge University Press.

Robbins, Stephen P. 2008. Perilaku Organisasi Buku 1, Edisi 12.Diterjemahkan oleh Diana Angelica. Jakarta: Salemba Empat.

Rusdiana, dan Heryati.(2015). Pendidikan Profesi Keguruan. Bandung. Pustaka setia.

Shaleh, Abdul Rahman.(2009). Psikologi Suatu Pengantar Dalam Perspektif Islam. Jakarta: Kencana.

Simamora, Bilson.(2002). Panduan Riset Perilaku Konsumen. Jakarta: Gramedia Pustaka Utama.

Sobur, Alex.(2009). Psikologi Umum. Bandung: Pustaka Setia.

Sugiyono. (2008). Metode Penelitian Kunatitatif Kualitatif dan R\&D. Bandung : Alfabeta.

Uno, Hamzah. (2014). Profesi Kependidikan. Jakarta: Bumi Aksara.

UU Republik Indonesia. (2006). Sisdiknas NO 20 Tahun 2003, Bandung: Fokusmedia.

Verner, K. (2000). A qualitative study of effective teacher behaviors. Chicago: Illinois University.

Walgito, B. (2002). Pengantar Psikologi Umum. Yokyakarta: Penerbit Andy Offset. 